4




Coordenação editorial: José Morais Arnaud, César Neves e Andrea Martins Design gráfico: Flatland Design

AAP - ISBN: 978-972-9451-89-8

CITCEM - ISBN: 978-989-8970-25-1

Associação dos Arqueólogos Portugueses e CITCEM

Lisboa, 2020

O conteúdo dos artigos é da inteira responsabilidade dos autores. Sendo assim a Associação dos Arqueólogos Portugueses declina qualquer responsabilidade por eventuais equívocos ou questões de ordem ética e legal.

Desenho de capa:

Planta do castro de Monte Mozinho (Museu Municipal de Penafiel).

\section{$\hat{\wedge} \mathrm{P}$}

DOS ARQUEÓLOGOS PORTUGUESES


MUSEU
ARQUELLÓGICO
DO CARMO
U.PORTO

FLUP FACULDADE DE LETRAS
UNIVERSIDADE DO PORTO

Apoio

EC para a Ciência 


\section{Índice}

15 Prefácio

José Morais Arnaud

\section{Historiografia e Teoria}

17 Território, comunidade, memória e emoção: a contribuição da história da arqueologia (algumas primeiras e breves reflexões)

Ana Cristina Martins

25 Como descolonizar a arqueologia portuguesa?

Rui Gomes Coelho

41 Arqueologia e Modernidade: uma revisitação pessoal e breve de alguns aspetos da obra homónima de Julian Thomas de 2004

Vítor Oliveira Jorge

57 Dados para a História das Mulheres na Arqueologia portuguesa, dos finais do século XIX aos inícios do século XX: números, nomes e tabelas

Filipa Dimas / Mariana Diniz

73 Retractos da arqueologia portuguesa na imprensa: (in)visibilidades no feminino

Catarina Costeira / Elsa Luís

85 Arqueologia e Arqueólogos no Norte de Portugal Jacinta Bugalhão

101 Vieira Guimarães (1864-1939) e a arqueologia em Tomar: uma abordagem sobre o território e as gentes

João Amendoeira Peixoto / Ana Cristina Martins

115 Os memoráveis? A arqueologia algarvia na imprensa nacional e regional na presente centúria (2001-2019): características, visões do(s) passado(s) e a arqueologia

enquanto marca

Frederico Agosto / João Silva

129 A Evolução da Arqueologia Urbana e a Valorização Patrimonial no Barlavento Algarvio: Os casos de Portimão e Silves

Artur Mateus / Diogo Varandas / Rafael Boavida

\section{Gestão, Valorização e Salvaguarda do Património}

145 O Caderno Reivindicativo e as condições de trabalho em Arqueologia Miguel Rocha / Liliana Matias Carvalho / Regis Barbosa / Mauro Correia / Sara Simões / Jacinta Bugalhão / Sara Brito / Liliana Veríssimo Carvalho / Richard Peace / Pedro Peça / Cézer Santos

155 Os Estudos de Impacte Patrimonial como elemento para uma estratégia sustentável de minimização de impactes no âmbito de reconversões agrícolas Tiago do Pereiro

165 Salvaguarda de Património arqueológico em operações florestais: gestão e sensibilização Filipa Bragança / Gertrudes Zambujo / Sandra Lourenço / Belém Paiva / Carlos Banha / Frederico Tatá Regala / Helena Moura / Jacinta Bugalhão / João Marques / José Correia / Pedro Faria / Samuel Melro

179 Os valores do Património: uma investigação sobre os Sítios Pré-históricos de Arte Rupestre do Vale do Rio Côa e de Siega Verde José Paulo Francisco 
189 Conjugando recursos arqueológicos e naturais para potenciar as visitas ao Geoparque Litoral de Viana do Castelo (Noroeste de Portugal)

Hugo A. Sampaio / Ana M.S. Bettencourt / Susana Marinho / Ricardo Carvalhido

203 Áreas de Potencial Arqueológico na Região do Médio Tejo: Modelo Espacial Preditivo Rita Ferreira Anastácio / Ana Filipa Martins / Luiz Oosterbeek

223 Património Arqueológico e Gestão Territorial: O contributo da Arqueologia para a revisão do PDM de Avis

Ana Cristina Ribeiro

237 A coleção arqueológica do extinto Museu Municipal do Porto - Origens, Percursos e Estudos

Sónia Couto

251 Valpaços - uma nova carta arqueológica

Pedro Pereira / Maria de Fátima Casares Machado

263 Arqueologia na Cidade de Peniche

Adriano Constantino / Luís Rendeiro

273 Arqueologia Urbana: a cidade de Lagos como caso de Estudo Cátia Neto

285 Estratégias de promoção do património cultural subaquático nos Açores. O caso da ilha do Faial

José Luís Neto / José Bettencourt / Luís Borges / Pedro Parreira

297 Carta Arqueológica da Cidade Velha: Uma primeira abordagem

Jaylson Monteiro / Nireide Tavares / Sara da Veiga / Claudino Ramos / Edson Brito /

Carlos Carvalho / Francisco Moreira / Adalberto Tavares

311 Antropologia Virtual: novas metodologias para a análise morfológica e funcional Ricardo Miguel Godinho / Célia Gonçalves

\section{Didáctica da Arqueologia}

327 Como os projetos de Arqueologia podem contribuir para uma comunidade culturalmente mais consciente Alexandra Figueiredo / Claúdio Monteiro / Adolfo Silveira / Ricardo Lopes

337 Educação Patrimonial - Um cidadão esclarecido é um cidadão ativo! Ana Paula Almeida

351 A aproximação da Arqueologia à sala de aula: um caso de estudo no $3^{\circ}$ ciclo do Ensino Básico Luís Serrão Gil

363 Arqueologia 3.o - Pensar e comunicar a Arqueologia para um futuro sustentável Mónica Rolo

377 “Conversa de Arqueólogos" - Divulgar a Arqueologia em tempos de Pandemia Diogo Teixeira Dias

389 Escola Profissional de Arqueologia: desafios e oportunidades Susana Nunes / Dulcineia Pinto / Júlia Silva / Ana Mascarenhas

399 Os Museus de Arqueologia e os Jovens: a oferta educativa para o público adolescente Beatriz Correia Barata / Leonor Medeiros

411 O museu universitário como mediador entre a ciência e a sociedade: o exemplo da secção de arqueologia no Museu de História Natural e da Ciência da Universidade do Porto (MHNC-UP)

Rita Gaspar 
421 Museu de Lanifícios: Real Fábrica de Panos. Atividades no âmbito da Arqueologia Beatriz Correia Barata / Rita Salvado

427 Arqueologia Pública e o caso da localidade da Mata (Torres Novas) Cláudia Manso / Ana Rita Ferreira / Cristiana Ferreira / Vanessa Cardoso Antunes

431 Do sítio arqueológico ao museu: um percurso (também) didático Lídia Fernandes

447 Estão todos convidados para a Festa! E para dançar também... O projecto do Serviço Educativo do Museu Arqueológico do Carmo na $5^{\underline{a}}$ Edição da Festa da Arqueologia Rita Pires dos Santos

459 O “Clã de Carenque”, um projeto didático de arqueologia Eduardo Gonzalez Rocha

469 Mediação cultural: peixe que puxa carroça nas Ruínas Romanas de Troia Inês Vaz Pinto / Ana Patrícia Magalhães / Patrícia Brum / Filipa Santos

481 Didática Arqueológica, experiências do Projeto Mértola Vila Museu Maria de Fátima Palma / Clara Rodrigues / Susana Gómez / Lígia Rafael

\section{Arte Rupestre}

497 Os inventários de arte rupestre em Portugal Mila Simões de Abreu

513 O projeto FIRST-ART - conservação, documentação e gestão das primeiras manifestações de arte rupestre no Sudoeste da Península Ibérica: as grutas do Escoural e Maltravieso Sara Garcês / Hipólito Collado / José Julio García Arranz / Luiz Oosterbeek / António Carlos Silva / Pierluigi Rosina / Hugo Gomes / Anabela Borralheiro Pereira / George Nash / Esmeralda Gomes / Nelson Almeida / Carlos Carpetudo

523 Trabalhos de documentação de arte paleolítica realizados no âmbito do projeto PalæoCôa André Tomás Santos / António Fernando Barbosa / Luís Luís / Marcelo Silvestre / Thierry Aubry

537 Imagens fantasmagóricas, silhuetas elusivas: as figuras humanas na arte do Paleolítico Superior da região do Côa Mário Reis

$55^{1}$ Os motivos zoomórficos representados nas placas de tear de Vila Nova de São Pedro (Azambuja, Portugal) Andrea Martins / César Neves / José M. Arnaud / Mariana Diniz

571 Arte Rupestre do Monte de Góios (Lanhelas, Caminha). Síntese dos resultados dos trabalhos efectuados em 2007-2009 Mário Varela Gomes

599 Gravuras rupestres de barquiformes no Monte de S. Romão, Guimarães, Noroeste de Portugal Daniela Cardoso

613 Círculos segmentados gravados na Bacia do Rio Lima (Noroeste de Portugal): contributos para o seu estudo Diogo Marinho / Ana M.S. Bettencourt / Hugo Aluai Sampaio

631 Equídeos gravados no curso inferior do Rio Mouro, Monção (NW Portugal). Análise preliminar Coutinho, L.M. / Bettencourt, A.M.S / Sampaio, Hugo A.S

645 Paletas na Arte Rupestre do Noroeste de Portugal. Inventário preliminar Bruna Sousa Afonso / Ana M. S. Bettencourt / Hugo A. Sampaio 


\section{Pré-História}

661 O projeto Miño/Minho: balanço de quatro anos de trabalhos arqueológicos Sérgio Monteiro-Rodrigues / João Pedro Cunha-Ribeiro / Eduardo Méndez-Quintas / Carlos Ferreira / Pedro Xavier / José Meireles / Alberto Gomes / Manuel Santonja / Alfredo Pérez-González

677 A ocupação paleolítica da margem esquerda do Baixo Minho: a indústria lítica do sítio de Pedreiras 2 (Monção, Portugal) e a sua integração no contexto regional Carlos Ferreira / João Pedro Cunha-Ribeiro / Sérgio Monteiro-Rodrigues / Eduardo Méndez-Quintas / Pedro Xavier / José Meireles / Alberto Gomes / Manuel Santonja / Alfredo Pérez-González

693 O sítio acheulense do Plistocénico médio da Gruta da Aroeira Joan Daura / Montserrat Sanz / Filipa Rodrigues / Pedro Souto / João Zilhão

703 As sociedades neandertais no Barlavento algarvio: modelos preditivos com recurso aos SIG

Daniela Maio

715 A utilização de quartzo durante o Paleolítico Superior no território dos vales dos rios Vouga e Côa

Cristina Gameiro / Thierry Aubry / Bárbara Costa / Sérgio Gomes / Luís Luís / Carmen Manzano / André Tomás Santos

733 Uma perspetiva diacrónica da ocupação do concheiro do Cabeço da Amoreira (Muge, Portugal) a partir da tecnologia lítica Joana Belmiro / João Cascalheira / Célia Gonçalves

745 Novos dados sobre a Pré-história Antiga no concelho de Palmela. A intervenção arqueológica no sítio do Poceirão I

Michelle Teixeira Santos

757 Problemas em torno de Datas Absolutas Pré-Históricas no Norte do Alentejo Jorge de Oliveira

771 Povoamento pré-histórico nas áreas montanhosas do NO de Portugal: o Abrigo 1 de Vale de Cerdeira Pedro Xavier / José Meireles / Carlos Alves

783 Apreciação do povoamento do Neolítico Inicial na Baixa Bacia do Douro. A Lavra I (Serra da Aboboreira) como caso de estudo Maria de Jesus Sanches

797 O Processo de Neolitização na Plataforma do Mondego: os dados do Sector C do Outeiro dos Castelos de Beijós (Carregal do Sal)

João Carlos de Senna-Martinez / José Manuel Quintã Ventura / Andreia Carvalho / Cíntia Maurício

823 Novos trabalhos na Lapa da Bugalheira (Almonda, Torres Novas) Filipa Rodrigues / Pedro Souto / Artur Ferreira / Alexandre Varanda / Luís Gomes / Helena Gomes / João Zilhão

837 A pedra polida e afeiçoada do sítio do Neolítico médio da Moita do Ourives (Benavente, Portugal)

César Neves

857 Casal do Outeiro (Encarnação, Mafra): novos contributos para o conhecimento do povoamento do Neolítico final na Península de Lisboa.

Cátia Delicado / Carlos Maneira e Costa / Marta Miranda / Ana Catarina Sousa

873 Stresse infantil, morbilidade e mortalidade no sítio arqueológico do Neolítico Final/ Calcolítico ( $4^{\circ}$ e $3^{\circ}$ milénio a.C.) do Monte do Carrascal 2 (Ferreira do Alentejo, Beja) Liliana Matias de Carvalho / Sofia N. Wasterlain 
885 Come together: O Conjunto Megalítico das Motas (Monção, Viana do Castelo) e as expressões Campaniformes do Alto Minho Ana Catarina Basílio / Rui Ramos

899 Trabalhos arqueológicos no sítio Calcolítico da Pedreira do Poio Carla Magalhães / João Muralha / Mário Reis / António Batarda Fernandes

913 O sítio arqueológico de Castanheiro do Vento. Da arquitectura do sítio à arquitectura de um território João Muralha Cardoso

925 Estudo zooarqueológico das faunas do Calcolítico final de Vila Nova de São Pedro (Azambuja, Portugal): Campanhas de 2017 e 2018 Cleia Detry / Ana Catarina Francisco / Mariana Diniz / Andrea Martins / César Neves / José Morais Arnaud

943 As faunas depositadas no Museu Arqueológico do Carmo provenientes de Vila Nova de São Pedro (Azambuja): as campanhas de 1937 a 1967 Ana Catarina Francisco / Cleia Detry / César Neves / Andrea Martins / Mariana Diniz / José Morais Arnaud

959 Análise funcional de material lítico em sílex do castro de Vila Nova de S. Pedro (Azambuja, Portugal): uma primeira abordagem Rafael Lima

971 O recinto da Folha do Ouro 1 (Serpa) no contexto dos recintos de fossos calcolíticos alentejanos

António Carlos Valera / Tiago do Pereiro / Pedro Valério / António M. Monge Soares

\section{Proto-História}

987 Produção de sal marinho na Idade do Bronze do noroeste Português. Alguns dados para uma reflexão

Ana M. S. Bettencourt / Sara Luz / Nuno Oliveira / Pedro P. Simões / Maria Isabel C. Alves / Emílio Abad-Vidal

1001 A estátua-menir do Pedrão ou de São Bartolomeu do Mar (Esposende, noroeste de Portugal) no contexto arqueológico da fachada costeira de entre os rios Neiva e Cávado Ana M. S. Bettencourt / Manuel Santos-Estévez / Pedro Pimenta Simões / Luís Gonçalves

1015 O Castro do Muro (Vandoma/Baltar, Paredes) - notas para uma biografia de ocupação da Idade do Bronze à Idade Média

Maria Antónia D. Silva / Ana M. S. Bettencourt / António Manuel S. P. Silva / Natália Félix

1031 Do Bronze Final à Idade Média - continuidades e hiatos na ocupação de Povoados em Oliveira de Azeméis João Tiago Tavares / Adriaan de Man

1041 As faunas do final da Idade do Bronze no Sul de Portugal: leituras desde o Outeiro do Circo (Beja)

Nelson J. Almeida / Íris Dias / Cleia Detry / Eduardo Porfírio / Miguel Serra

1055 A Espada do Monte das Oliveiras (Serpa) - uma arma do Bronze Pleno do Sudoeste Rui M. G. Monge Soares / Pedro Valério / Mariana Nabais / António M. Monge Soares

1065 São Julião da Branca (Albergaria-a-Velha) - Investigação e valorização de um povoado do Bronze Final

António Manuel S. P. Silva / Paulo A. P. Lemos / Sara Almeida e Silva / Edite Martins de Sá

1083 Do castro de S. João ao Mosteiro de Santa Clara: notícia de uma intervenção arqueológica, em Vila do Conde Rui Pinheiro 
1095 O castro de Ovil (Espinho), um quarto de século de investigação - resultados e questões em aberto

Jorge Fernando Salvador / António Manuel S. P. Silva

1111 O Castro de Salreu (Estarreja), um povoado proto-histórico no litoral do Entre Douro e Vouga

Sara Almeida e Silva / António Manuel S. P. Silva / Paulo A. P. Lemos / Edite Martins de Sá

1127 Castro de Nossa Senhora das Necessidades (Sernancelhe): uma primeira análise artefactual Telma Susana O. Ribeiro

${ }_{1141}$ A cividade de Bagunte. O estado atual da investigação Pedro Brochado de Almeida

1153 Zoomorfos na cerâmica da Idade do Ferro no NW Peninsular: inventário, cronologias e significado Nuno Oliveira / Cristina Seoane

1163 Vasos gregos em Portugal: diferentes maneiras de contar a história do intercâmbio cultural na Idade do Ferro

Daniela Ferreira

1175 Os exotica da necrópole da Idade do Ferro do Olival do Senhor dos Mártires (Alcácer do Sal) no seu contexto regional

Francisco B. Gomes

\section{Antiguidade Clássica e Tardia}

1191 O uso de madeira como combustível no sítio da Quinta de Crestelos (Baixo Sabor): da Idade do Ferro à Romanização Filipe Vaz / João Tereso / Sérgio Simões Pereira / José Sastre / Javier Larrazabal Galarza / Susana Cosme / José António Pereira / Israel Espi

1207 Cultivos de Época Romana no Baixo Sabor: continuidade em tempos de mudança? João Pedro Tereso / Sérgio Simões Pereira / Filipe Santos / Luís Seabra / Filipe Vaz

1221 A casa romana na Hispânia: aplicação dos modelos itálicos nas províncias ibéricas Fernanda Magalhães / Diego Machado / Manuela Martins

1235 As pinturas murais romanas da Rua General Sousa Machado, n. ${ }^{5}$ 1, Chaves José Carvalho

1243 Trás do Castelo (Vale de Mir, Pegarinhos, Alijó) - Uma exploração agrícola romana do Douro

Tony Silvino / Pedro Pereira

1255 A sequência de ocupação no quadrante sudeste de Bracara Augusta: as transformações de uma unidade doméstica Lara Fernandes / Manuela Martins

1263 Os Mosaicos com decoração geométrica e geométrico-vegetalista dos sítios arqueológicos da área do Conuentus Bracaraugustanus. Novas abordagens quanto à conservação, restauro, decoração e datação Maria de Fátima Abraços / Licínia Wrench

1277 “Casa Romana” do Castro de São Domingos (Cristelos, Lousada): Escavação, Estudo e Musealização Paulo André de P. Lemos

1291 A arqueobotânica no Castro de Guifões (Matosinhos, Noroeste de Portugal): O primeiro estudo carpológico

Luís Seabra / Andreia Arezes / Catarina Magalhães / José Varela / João Pedro Tereso 
1305 Um Horreum Augustano na Foz do Douro (Monte do Castelo de Gaia, Vila Nova de Gaia) Rui Ramos

1311 Ponderais romanos na Lusitânia: padrões, formas, materiais e contextos de utilização Diego Barrios Rodríguez

1323 Um almofariz centro-itálico na foz do Mondego

Marco Penajoia

1335 Estruturas romanas de Carnide - Lisboa Luísa Batalha / Mário Monteiro / Guilherme Cardoso

1347 O contexto funerário do sector da "necrópole NO" da Rua das Portas de S. Antão (Lisboa): o espaço, os artefactos, os indivíduos e a sua interconectividade na interpretação do passado Sílvia Loja, José Carlos Quaresma, Nelson Cabaço, Marina Lourenço, Sílvia Casimiro, Rodrigo Banha da Silva, Francisca Alves-Cardoso

${ }_{1361}$ Povoamento em época Romana na Amadora - resultados de um projeto pluridisciplinar Gisela Encarnação / Vanessa Dias

1371 A Arquitectura Residencial em Mirobriga (Santiago do Cacém): contributo a partir de um estudo de caso Filipe Sousa / Catarina Felício

${ }_{1385}$ O fim do ciclo. Saneamento e gestão de resíduos nos edifícios termais de Mirobriga (Santiago do Cacém)

Catarina Felício / Filipe Sousa

1399 Balsa, Topografia e Urbanismo de uma Cidade Portuária Vítor Silva Dias / João Pedro Bernardes / Celso Candeias / Cristina Tété Garcia

1413 No Largo das Mouras Velhas em Faro (2017): novas evidências da necrópole norte de Ossonoba e da sua ocupação medieval Ricardo Costeira da Silva / Paulo Botelho / Fernando Santos / Liliana Nunes

1429 Instrumentos de pesca recuperados numa fábrica de salga em Ossonoba (Faro) Inês Rasteiro / Ricardo Costeira da Silva / Paulo Botelho

1439 A Necrópole Romana do Eirô, Duas Igrejas (Penafiel): intervenção arqueológica de 2016 Laura Sousa / Teresa Soeiro

1457 Ritual, descarte ou afetividade? A presença de Canis lupus familiaris na Necrópole Noroeste de Olisipo (Lisboa)

Beatriz Calapez Santos / Sofia Simões Pereira / Rodrigo Banha da Silva / Sílvia Casimiro / Cleia Detry / Francisca Alves Cardoso

1467 Dinâmicas económicas em Bracara na Antiguidade Tardia Diego Machado / Manuela Martins / Fernanda Magalhães / Natália Botica

1479 Cerâmicas e Vidros da Antiguidade Tardia do Edifício sob a Igreja do Bom Jesus (Vila Nova de Gaia) Joaquim Filipe Ramos

1493 Novos contributos para a topografia histórica de Mértola no período romano e na Antiguidade Tardia Virgílio Lopes

\section{8. Época Medieval}

1511 Cerâmicas islâmicas no Garb setentrional "português": algumas evidências e incógnitas Constança dos Santos / Helena Catarino / Susana Gómez / Maria José Gonçalves / Isabel Inácio / Gonçalo Lopes / Jacinta Bugalhão / Sandra Cavaco / Jaquelina Covaneiro / Isabel Cristina Fernandes / Ana Sofia Gomes 
1525 Contributo para o conhecimento da cosmética islâmica, em Silves, durante a Idade Média Rosa Varela Gomes

1537 Yábura e o seu território - uma análise histórico-arqueológica de Évora entre os séculos VIII-XII José Rui Santos

1547 A encosta sul do Castelo de Palmela - resultados preliminares da escavação arqueológica Luís Filipe Pereira / Michelle Teixeira Santos

1559 A igreja de São Lourenço (Mouraria, Lisboa): um conjunto de silos e de cerâmica medieval islâmica

Andreia Filipa Moreira Rodrigues

1571 O registo material de movimentações populacionais no Médio Tejo, durante os séculos XII-XIII. Dois casos de "sunken featured buildings", nos concelhos de Cartaxo e Torres Novas Marco Liberato / Helena Santos / Nuno Santos

1585 O nordeste transmontano nos alvores da Idade média. Notas para reflexão Ana Maria da Costa Oliveira

1601 Sepulturas escavadas na rocha do Norte de Portugal e do Vale do Douro: primeiros resultados do Projecto SER-NPVD

Mário Jorge Barroca / César Guedes / Andreia Arezes / Ana Maria Oliveira

1619 "Portucalem Castrum Novum" entre o Mediterrâneo e o Atlântico: o estudo dos materiais cerâmicos alto-medievais do arqueossítio da rua de D. Hugo, nํ. 5 (Porto) João Luís Veloso

1627 A Alta Idade Média na fronteira de Lafões: notas preliminares sobre a Arqueologia no Concelho de Vouzela

Manuel Luís Real / Catarina Tente

1641 Um conjunto cerâmico medieval fora de portas: um breve testemunho aveirense Susana Temudo

${ }_{1651}$ Os Lóios do Porto: uma perspetiva integrada no panorama funerário da Baixa Idade Média à Época Moderna em meios urbanos em Portugal

Ana Lema Seabra

1659 O Caminho Português Interior de Santiago como eixo viário na Idade Média Pedro Azevedo

1665 Morfologia Urbana: Um exercício em torno do Castelo de Ourém André Donas-Botto / Jaqueline Pereira

1677 Intervenção arqueológica na Rua Marquês de Pombal/Largo do Espírito Santo (Bucelas, Loures)

Florbela Estêvão / Nathalie Antunes-Ferreira / Dário Ramos Neves / Inês Lisboa

1691 O Cemitério Medieval do Poço do Borratém e a espacialidade funerária na cidade de Lisboa Inês Belém / Vanessa Filipe / Vasco Noronha Vieira / Sónia Ferro / Rodrigo Banha da Silva

1705 Um Espaço Funerário Conventual do séc. XV em Lisboa: o caso do Convento de São Domingos da Cidade Sérgio Pedroso / Sílvia Casimiro / Rodrigo Banha da Silva / Francisca Alves Cardoso

\section{9. Época Moderna e Contemporânea}

1721 Arqueologia Moderna em Portugal: algumas reflexões críticas em torno da quantificação de conjuntos cerâmicos e suas inferências históricas e antropológicas Rodrigo Banha da Silva / André Bargão / Sara da Cruz Ferreira

1733 Faianças de dois contextos entre os finais do século XVI e XVIII do Palácio dos Condes de Penafiel, Lisboa

Martim Lopes / Tomás Mesquita 
1747 Um perfil de consumo do século XVIII na foz do Tejo: O caso do Mercado da Ribeira, Lisboa Sara da Cruz Ferreira / Rodrigo Banha da Silva / André Bargão

1761 Os Cachimbos dos Séculos XVII e XVIII do Palácio Mesquitela e Convento dos Inglesinhos (Lisboa)

Inês Simão / Marina Pinto / João Pimenta / Sara da Cruz Ferreira / André Bargão / Rodrigo Banha da Silva

1775 "Tomar os fumos da erua que chamão em Portugal erua sancta». Estudo de Cachimbos provenientes da Rua do Terreiro do Trigo, Lisboa

Miguel Martins de Sousa / José Pedro Henriques / Vanessa Galiza Filipe

1787 Cachimbos de Barro Caulínitico da Sé da Cidade Velha (República de Cabo Verde)

Rodrigo Banha da Silva / João Pimenta / Clementino Amaro

1801 Algumas considerações sobre espólio não cerâmico recuperado no Largo de Jesus (Lisboa) Carlos Boavida

1815 Adereços de vidro, dos séculos XVI-XVIII, procedentes do antigo Convento de Santana de Lisboa (anéis, braceletes e contas)

Joana Gonçalves / Rosa Varela Gomes / Mário Varela Gomes

1837 Da ostentação, luxo e poder à simplicidade do uso quotidiano: arqueologia e simbologia de joias e adornos da Idade Moderna Portuguesa Jéssica Iglésias

1849 Os amuletos em Portugal - dos objetos às superstições: o coral vermelho Alexandra Vieira

1865 Cerâmicas de Vila Franca de Xira nos séculos XV e XVI Eva Pires

1879 «Não passa por teu o que me pertence». Marcas de individualização associadas a faianças do Convento de Nossa Senhora de Aracoeli, Alcácer do Sal Catarina Parreira / Íris Fragoso / Miguel Martins de Sousa

1891 Cerâmica de Leiria: alguns focos de produção

Jaqueline Pereira / André Donas-Botto

1901 Os Fornos na Rua da Biquinha, em Óbidos Hugo Silva / Filipe Oliveira

1909 A casa de Pêro Fernandes, contador dos contos de D. Manuel I: o sítio arqueológico da Silha do Alferes, Seixal (século XVI) Mariana Nunes Ferreira

1921 O Alto da Vigia (Sintra) e a vigilância e defesa da costa Alexandre Gonçalves / Sandra Santos

1937 O contexto da torre sineira da Igreja de Santa Maria de Loures Paulo Calaveira / Martim Lopes

1949 A Necrópole do Hospital Militar do Castelo de São Jorge e as práticas funerárias na Lisboa de Época Moderna Susana Henriques / Liliana Matias de Carvalho / Ana Amarante / Sofia N. Wasterlain

1963 SAND - Sarilhos Grandes Entre dois Mundos: o adro da Igreja e a Paleobiologia dos ossos humanos recuperados

Paula Alves Pereira / Roger Lee Jesus / Bruno M. Magalhães

1975 Expansão urbana da vila de Cascais no século XVII e XVIII: a intervenção arqueológica na Rua da Vitória no 15 a 17

Tiago Pereira / Vanessa Filipe

1987 Novos dados para o conhecimento do Urbanismo de Faro em época Moderna Ana Rosa 
1995 Um exemplo de Arqueologia Urbana em Alcoutim: o Antigo Edifício dos CTT Marco Fernandes / Marta Dias / Alexandra Gradim / Virgílio Lopes / Susana Gómez Martínez

2007 Palácio dos Ferrazes (Rua das Flores/Rua da Vitória, Porto): a cocheira de Domingos Oliveira Maia

Francisco Raimundo

2021 As muitas vidas de um edifício urbano: História, Arqueologia e Antropologia no antigo Recreatório Paroquial de Penafiel Helena Bernardo / Jorge Sampaio / Marta Borges

2035 O convento de Nossa Senhora da Esperança de Ponta Delgada: o contributo da arqueologia para o conhecimento de um monumento identitário João Gonçalves Araújo / N’Zinga Oliveira

2047 Arqueologia na ilha do Corvo... em busca da capela de Nossa Senhora do Rosário Tânia Manuel Casimiro / José Luís Neto / Luís Borges / Pedro Parreira

2059 Perdidos à vista da Costa. Trabalhos arqueológicos subaquáticos na Barra do Tejo Jorge Freire / José Bettencourt / Augusto Salgado

2071 Arqueologia marítima em Cabo Verde: enquadramento e primeiros resultados do projecto CONCHA

José Bettencourt / Adilson Dias / Carlos Lima / Christelle Chouzenoux / Cristóvão Fonseca / Dúnia Pereira / Gonçalo Lopes / Inês Coelho / Jaylson Monteiro / José Lima / Maria Eugénia Alves / Patrícia Carvalho / Tiago Silva

2085 Trabalhos arqueológicos na Cidade Velha (Ribeira Grande de Santiago, Cabo Verde): reflexões sobre um projecto de investigação e divulgação patrimonial André Teixeira / Jaylson Monteiro / Mariana Mateus / Nireide Tavares / Cristovão Fonseca / Gonçalo C. Lopes / Joana Bento Torres / Dúnia Pereira / André Bargão / Aurélie Mayer / Bruno Zélie / Carlos Lima / Christelle Chouzenoux / Inês Henriques / Inês Pinto Coelho / José Lima / Patrícia Carvalho / Tiago Silva

2103 A antiga fortificação de Quelba / Khor Kalba (E.A.U.). Resultados de quatro campanhas de escavações, problemáticas e perspectivas futuras Rui Carita / Rosa Varela Gomes / Mário Varela Gomes / Kamyar Kamyad

2123 Colónias para homens novos: arqueologia da colonização agrária fascista no noroeste ibérico Xurxo Ayán Vila / José Mạ . Señorán Martín 


\title{
OS MUSEUS DE ARQUEOLOGIA E OS JOVENS: A OFERTA EDUCATIVA PARA O PÚBLICO ADOLESCENTE
}

\author{
Beatriz Correia Barata ${ }^{1}$, Leonor Medeiros ${ }^{2}$
}

\begin{abstract}
RESUMO
A dinâmica dos serviços educativos dos museus tem vindo a desenvolver-se de forma significativa como resposta à valorização e divulgação do património junto dos diferentes públicos. Contudo, os visitantes e os interesses mudam, levando não só à adaptação por parte dos museus, mas também à necessidade de captar audiências e ir de encontro aos novos interesses.

É dentro do âmbito de captação de novos públicos em museus de arqueologia que se foca este artigo, mais precisamente no público entre os 13 e os 17 anos, que se tem provado um desafio. O adolescente é um público com necessidades específicas e numa fase de transição. No entanto, este é um período fundamental para a educação e formação do futuro adulto/visitante.
\end{abstract}

Palavras-chave: Arqueologia, Adolescentes, Museus, Educação, Atividades.

\begin{abstract}
In the last decades, the museums have shown a strong growth in the dynamics of their educational services, both at national and international level. These dynamics appeared, above all, in response to the need to conserve and enrich the cultural heritage and to educate the different audiences.

However, the audiences and the interests change over time and the museums need to adapt and pursue these changes. Therefore, the need to meet the new interests and to attract new audiences has become increasingly relevant and substantial.

This study focuses on the necessity of attracting new audiences in archaeological museums, more precisely on the teen audience between $13^{\text {th }}$ and $17^{\text {th }}$ years old, that has proved to be a challenge.

Keywords: Archaeology, Teen, Museums, Education, Activities.
\end{abstract}

\section{A ARQUEOLOGIA E O ADOLESCENTE - UM DESAFIO À COMUNICAÇÃO}

A arqueologia detém nos dias de hoje um grande interesse por parte do público, tanto de "miúdos" como de "graúdos". A popularidade da disciplina não se deve tanto aos materiais arqueológicos, embora pesem as descobertas que os envolve, mas ao que tem vindo a ser "fantasiado" desde as grandes descobertas dos finais do século XIX e século XX. Para o grande público a arqueologia é sinónimo de aventura e mistério em locais exóticos, e o arqueólogo é o protagonista, um "detetive" que investiga o passado juntando várias peças do puzzle (HOLTORF, 2004). A televisão e as produções cinematográficas têm grande destaque relativamente à produção desta imagem, uma vez que se tornaram desde cedo num importante veículo para apresentar o passado ao grande público e consecutivamente atingir grandes índices de audiência (BAHN, 1997), variando das representações mais fantasiosas como os filmes Indiana Jones, às mais científicas como a série televisiva britânica Time Team. A imagem apresentada ao grande público através dos media e outras entidades ligadas ao desenvolvimento de atividades culturais tendem a ser, na sua grande maioria, bastante fan-

1. beatrizcorreiabarata@gmail.com

2. Faculdade de Ciências Sociais e Humanas da Universidade Nova de Lisboa; lapmedeiros@gmail.com 
tasiosas e inclusive pouco éticas no que toca à representação da arqueologia e do arqueólogo. É efetivamente face a esta imagem incorreta e dominante junto do grande público que há a necessidade crescente de uma maior valorização e proteção do património arqueológico, onde a educação patrimonial se torna essencial, uma vez que o seu objetivo primordial é educar e criar uma ligação próxima entre a sociedade e o seu património artístico, histórico e arqueológico.

Éprecisamentenoâmbitodaeducaçãoecomunicação patrimonial que os museus de arqueologia surgem como um agente importante, uma vez que são locais onde se promove a importância e preservação do objecto arqueológico, a valorização e investigação de coleções arqueológicas, a divulgação e a educação patrimonial (ANTAS, 2013). Por comunicação educativa em museus de arqueologia entenda-se todas as atividades realizadas, apoiadas por mediadores de aprendizagem, com base em recursos didáticos e museográficos que permitem uma comunicação unilateral e interativa com diversos públicos (ANTAS, 2013) e possibilitam novas formas de aprendizagem da arqueologia.

Contudo, para que esta comunicação patrimonial seja eficaz, deve ser considerada a importância da sua adaptação aos diversos tipos de público e não a um "público geral". Assim, os museus têm vindo a intensificar a investigação dos seus públicos de modo a desenvolver novas estratégias de captação (SANTOS, 2014; LOURENÇO, 2014, MATSUDA, 2004, 2016), aperfeiçoar as atividades e consequentemente a ampliar os seus públicos (ALMEIDA, 2005).

Na estrutura orgânica dos museus, o serviço educativo desempenha um papel essencial nesta comunicação educacional, uma vez que o seu principal objetivo é precisamente o desenvolvimento de estratégicas pedagógicas educacionais e a mediação natural do público. Ao serviço educativo compete, portanto, o desenvolvimento de programas, projetos e atividades pedagógicas adaptadas, a aprendizagem ativa e entretenimento de todos os tipos de público.

Os museus de arqueologia não são excepção. Aqui os serviços educativos dedicam-se à descodificação, comunicação e divulgação da mensagem arqueológica de forma clara e interativa. Os programas não devem reduzir-se à construção de materiais didáticos ou à adaptação do discurso científico a um discurso descodificado para os diferentes públicos. Com efeito, os programas desenvolvidos pela maioria dos ser- viços educativos de hoje são bastante diversificados, porém dirigem-se essencialmente ao público infanto-juvenil, grupos escolares e adultos.

Contudo, existe um público que tende a ser um pouco negligenciado pelos serviços educativos dos museus de arqueologia e museus em geral: o adolescente. É notório que este público é dos mais difíceis de cativar no âmbito de uma visita, porém poucos são os esforços da maioria dos serviços educativos para uma comunicação eficiente junto deste. Estes jovens detêm características demarcadas não só pela condição sociocultural onde estão inseridos (CARDOSO, 2013), mas também pelas características inerentes ao próprio período da adolescência. Estas particularidades devem ser assumidas pelos museus, considerando o adolescente como um tipo de público específico que não se integra no público infantil ou no público adulto. Face às suas caraterísticas especificas, têm vindo a ser desenvolvidos estudos que procuram identificar as principais razões relacionadas à baixa participação dos jovens nos museus.

A imagem do museu como um "local aborrecido" tem sido identificada como o principal motivo para o baixo número de visitantes adolescentes. Os jovens veem os museus como instituições pouco atraentes e fortemente estruturadas, onde as exposições, para além de aborrecidas, são inacessíveis e extramente protegidas (KELLY, BARTLETT, 2009). Este público deseja interagir com as exposições e testar as suas habilidades, no entanto, a maioria das atividades interativas são destinadas às crianças e, portanto, não se adequam à sua idade (SHRAPNEL, 2012).

Outro aspeto importante é o facto de o adolescente considerar o museu como um espaço que não vai de encontro às suas necessidades e desejos. Com a introdução das redes sociais, a forma como os jovens recebem informações mudou profundamente e, com estas mudanças, vieram novos valores, necessidades e desejos. $\mathrm{O}$ adolescente deseja contruir conhecimento em conjunto e num ambiente social onde se sinta à vontade para aprender e partilhar ideias (KORN, 2008).

Um outro factor identificado é o impacto de experiências negativas na percepção do jovem em relação aos museus. Memórias de visitas obrigatórias condicionadas ao plano escolar influenciam significativamente na decisão de futuras visitas (KELLY, BARLETT, 2009), porque estão associadas simplesmente a um complemento educativo e não a entretenimen- 
to (ANDERSON, HORLOCK, JACKSON 2000).

A questão financeira é identificada como uma outra barreira importante sendo que a maioria dos jovens são estudantes com uma restrição significativa de dinheiro (KELLY, BARLETT, 2009). E por fim, o factor da "zona de conforto", ou falta dela, é uma importante condicionante. A maioria dos jovens veem os museus como instituições formais e pouco convidativas (MCCARTHY, MANSON, 2006; KORN, 2008).

Com base nestes factores, acreditamos ser essencial não só transformar o modo de interação com os jovens, mas também repensar os programas educativos a eles dirigidos, o que por sua vez requer o desenvolvimento de estratégias de mediação e comunicação. No que respeita ao público adolescente, a estratégia do museu deve atender a três fatores importantes: compromisso, envolvimento e programas. Os programas precisam de compromisso institucional para atender às necessidades deste público, isto é, colaborações e parcerias, apoio ao programa, tempo, recursos e trabalho em equipa (KELLY, BARTLETT, 2009). Os programas e exibições devem explorar temas que cativem e atendam às necessidades e interesses deste público (KELLY, BARTLETT, 2009).

Um outro fator reside em tornar o museu mais participativo, um local onde os visitantes possam criar, partilhar e conectar-se tanto com a exposição como com outros visitantes (SIMON, 2010).

Por fim, é necessário fazer da instituição museológica um espaço menos formal do ponto de vista educativo e mais informal e convidativo, que possa ser considerado como um destino atrativo para os jovens (SHRAPNEL, 2012). O adolescente gosta de socializar, de ser participativo e de demonstrar o seu potencial, e o museu, como uma instituição cultural com impacto social, tem capacidade não só de integrar os jovens nestes aspetos, como também mostrar o seu potencial (BIRKETT, 2012).

Estes jovens não consideram o museu como parte dos seus circuitos de lazer, o que por sua vez leva a uma grande diminuição das suas visitas (CARDOSO, 2013). A educação formal ocupa boa parte do seu tempo, e o próprio museu tem sido apresentado como um complemento educacional pelas próprias instituições escolares, logo a perceção de que o museu é um local formal e disciplinado está presente na maioria dos adolescentes (FAUSTINI, 2012). Desta forma, o museu deve tornar-se para o jovem num local onde seja possível desenvolver sentido de identidade pessoal, fortalecer relações pessoais, adquirir novos conhecimentos, talentos e habilidades (KELLY, BARTLETT, 2009).

É importante captar este segmento de público e atender ao conjunto de factores que visam melhorar a comunicação com o mesmo, não só porque são uma parte da audiência substancial, mas também porque são a próxima geração de adultos e, consequentemente, futuros visitantes (KELLY, BARLETT, 2009).

Relativamente à relação do jovem com os museus arqueológicos, em termos teóricos, as instituições podem ter bastante sucesso junto deste público pois é uma ciência que detém um certo fascínio e curiosidade, devido essencialmente às ideias fantasiosas transmitidas por filmes, literatura e videojogos que fazem da disciplina um tema popular junto dos jovens. Do ponto de vista educacional a arqueologia tem capacidade de consciencializar os jovens do espaço envolvente, desenvolver o pensamento lógico e raciocínio científico, estimular a investigação, interpretação e a multidisciplinaridade, uma vez que trabalha em conjunto com outras ciências, como a química, a biologia, a geografia e as ciências tecnológicas (CRACKNELL, CORBSIHLEY 1986).

Considerando os fatores enunciados, que poderão justificar a baixa participação do adolescente nos museus de arqueologia, estarão estes preparados a nível de estruturação comunicativa para trabalhar com o público entre os 13 e os 17 anos? De modo a compreender de forma mais directa as relações dos museus de arqueologia com os jovens foram selecionados um conjunto de casos nacionais e internacionais.

\section{PROGRAMAS NACIONAIS E INTERNACIONAIS - ANÁLISE E DISCUSSÃO}

A seleção de um conjunto de projectos para análise deveu-se essencialmente à necessidade de avaliar programas educativos em museus de arqueologia, nacionais e internacionais, que considerámos exemplares e inovadores no que respeita à comunicação educativa. Apesar de ser nosso objectivo estudar o panorama nacional, considerámos importante apresentar também alguns modelos internacionais de forma a analisar alguns paralelos e contrastes em relação aos programas educativos selecionados em Portugal.

A seleção foi realizada a partir de diversos factores que avaliámos como "boas práticas" no desenvolvi- 
mento de atividades de comunicação do património arqueológico. Destes fatores considerámos não só o serviço e programa educativo, mas também a conceção do próprio espaço museológico para uma sensibilização e comunicação eficiente junto do público adolescente, entre os 13 e os 17 anos.

Os museus nacionais, mais do que exemplos de boas práticas foram ainda o centro de um estudo de caso, em que a análise dos seus programas foi colmatada com a realização de breves entrevistas, de forma a analisar directamente a sua oferta educativa e relação com o público em estudo.

Relativamente ao programa dos casos internacionais, patente na tabela apresentada (Tabela 1), podemos concluir que muitas das atividades baseiam-se essencialmente em projetos com base no manuseamento de materiais arqueológicos, hands-on, e em atividades criativas. Uma vez que se trata de museus arqueológicos revela-se uma forte presença da arqueologia experimental. Este tipo de atividade, para além de ser um método educativo extremamente eficaz, providencia ao visitante a experiência de assistir aos processos e ações que definiram o quotidiano do passado (COLOMER, 2002).

Uma característica importante são as atividades desenvolvidas para o público em estudo. Estas são direcionadas para intervalos de idade específicos, isto é, entre os 12 e os 14 anos e entre os 15 e os 18 anos. Existe, portanto, uma preocupação por parte dos serviços educativos destes museus em completar o seu programa com atividades criativas e participativas que sejam dirigidas a este público específico.

Quanto aos parques arqueológicos, não se pode deixar de examinar a sua forte componente comunicacional. Mais do que museus ou centros interpretativos são locais imersivos onde se tenta recriar uma realidade do passado, o que por sua vez atrai uma maior diversidade de público, incluindo os jovens. Os ambientes não são fantasiosos, mas sim do próprio quotidiano, permitindo aos visitantes estabelecer uma ligação entre o passado e o presente. A educação, contudo, não é a única razão para a criação de reconstruções arqueológicas. Há a parte da componente comunicativa, estes parques contribuem também para a publicidade e promoção do património arqueológico.

Dos casos nacionais analisados destaca-se a realização de atividades diversificadas e interativas que não só são dedicadas aos diversos públicos como estimulam a participação social (Tabela 2). A reali- zação de oficinas, ateliês e visitas jogos direcionados essencialmente para o público infantil, público juvenil e, por vezes, ao público sénior, têm não só fortes capacidades criativas e educativas como também estimulam a socialização entre público através da partilha de ideias e sugestões. Os workshops, palestras e conferências são dedicadas ao público adulto, sénior e público especializado, também com uma forte componente social e educacional. São atividades direcionadas para a descodificação e partilha de informação arqueológica a todo o público. Outra característica importante é a adaptação de todas estas atividades ao público com necessidades especiais, que vai desde a preparação do próprio espaço museológico à monitorização profissional por parte do serviço educativo.

Uma outra boa prática destes museus é o seu carácter participativo que permite aos visitantes estabelecer um contacto direto com a exposição e acervo do museu, permitindo uma leitura mais pessoal. Esta iniciativa não é apenas fundada nas atividades que permitem o manuseamento de objetos arqueológicos, como as oficinas de arqueologia experimental do Museu Arqueológico do Carmo e do Museu do Côa, mas também na própria exposição, como no museu Portugal Romano em Sicó, cuja exibição é à base da interatividade com a integração de recursos didáticos que captam o público.

Destacam-se também os serviços informativos dedicados aos visitantes, reais e virtuais, a partir de uma comunicação presencial ou à distância. Como é o caso da Rede de Clubes de Arqueologia do Museu Nacional de Arqueologia que através de uma plataforma online procura estender a educação patrimonial às escolas, ou o Ludi Saecularis do Museu Regional de Arqueologia D. Diogo de Sousa, um jogo simples baseado nos típicos jogos de tabuleiro, que dá a conhecer diversos aspetos acerca da presença romana no território português.

Por fim destaca-se a Festa da Arqueologia realizada nas ruínas do Convento do Carmo, um evento sobre arqueologia num contexto informal. Para além de se realizar num importante ponto turístico da cidade, é um excelente método de comunicação educativa que se tem mostrado cada vez mais eficiente.

Uma educação patrimonial acessível e inclusiva, exposições participativas que apelam a uma aprendizagem ativa e a realização de atividades interativas e criativas, que possibilitam uma participação de todo o tipo de públicos, são estratégias que fazem destes 
museus modelos exemplares na comunicação educativa em arqueologia.

Contudo, considerando todos estes aspectos positivos verificamos que os programas incluem o público em estudo, mas são escassas as atividades direcionadas especificamente aos adolescentes entre os 13 e os 17 anos. Em muitos dos casos estas atividades são concebidas para os jovens desde os 6 aos 14 anos (1ํㅜㄴㅡㅜ e $3^{\circ}$ Ciclo do Ensino Básico) sendo as atividades para os jovens entre os 15 e os 17 anos (Secundário) praticamente integradas no mesmo programa.

As visitas guiadas aos Tesouros da Arqueologia Portuguesa e Antiguidades Egípcias no MNA são a única atividade que abrange os jovens entre os $15 \mathrm{e}$ os 17, as restantes incluem os jovens entre os 13 e os 14, mas incluem também crianças desde os 6 anos. No MAC, a visita-jogo da temática da Idade Média, a visita-jogo da Salvaguarda do Património e as atividades temáticas relacionadas com o 25 de Abril são as únicas que abrangem o público em estudo, sendo a visita-jogo da Idade Média é a única específica para jovens entre os 16 e os 18 anos.

O Museu Regional D. Diogo de Sousa, por sua vez, não tem atividades dedicadas ao público com mais de 14 anos, excetuando um jogo de tabuleiro. No Museu do Côa verifica-se o mesmo, em que apenas uma atividade pedagógica abrange parte do nosso público, e as visitas guiadas, que são dedicadas a todos os contextos escolares.

Nos exemplos internacionais podemos ver algumas diferenças neste aspeto em que, apesar da mesma estratificação do público por nível escolar e algumas atividades em comum entre diferentes níveis de ensino, é possível identificar a existência de atividades dedicadas exclusivamente aos jovens entre os $12 \mathrm{e}$ os 14 ( $3^{\circ}$ ciclo do Ensino Básico), e outras exclusivas aos jovens entre os 15 e 18 (Ensino Secundário). Esta é uma estratificação do programa que, quando comparada com o nosso modelo, consideramos mais eficiente.

\subsection{Análise e Discussão}

O fator da educação patrimonial nos programas não só visa promover a difusão cultural e transmitir conhecimentos à sociedade, como também é essencial para a preservação e valorização do próprio património arqueológico. Uma educação patrimonial em arqueologia tem como principal objetivo criar uma ligação entre o património arqueológico e a socieda- de e, consequentemente, fortalecer os sentimentos de identidade, cidadania e inclusão.

No caso dos museus de arqueologia, uma comunicação educativa eficiente tem de analisar novas formas de aprender arqueologia, e deve ser interativa e adequada aos diversos públicos (ANTAS, 2013). É na realização do próprio programa que o serviço educativo do museu deve ter em consideração os fatores seguidamente identificados.

A importância da arqueologia e do objeto arqueológico, não só a nível didático, mas também como um objeto comunicante com características específicas. Aqui a organização da exposição é igualmente importante. Mais do que uma ordem cronológica e legendas de identificação, as peças devem integrar um contexto e uma ou várias temáticas. $\mathrm{O}$ museu PO.RO.S, por exemplo, organiza a sua exposição de uma forma essencialmente temática, onde em espaços distintos são apresentados diferentes aspetos do tema romano, desde as legiões à vida quotidiana, estabelecendo sempre um paralelo com o presente e com a própria arqueologia.

Os recursos didáticos são outro fator essencial que pode fazer parte da própria exposição ou ser utilizado em ações específicas para os públicos. Obstante ao seu contexto, todos têm o mesmo objetivo, auxiliar, melhorar e facilitar a comunicação educativa ao público. Aqui é importante destacar as salas de realidade aumentada, réplicas de tamanho original e maquetas ${ }_{3}$ D interativas do museu PO.RO.S, e também o jogo "Ludi Saeculares" do Museu D. Diogo de Sousa, um recurso didático que pode ser usado no museu, na escola e em casa. No caso dos museus nacionais identificados a maioria destes recursos tecnológicos tomam a forma de quadros e maquetas interativas integradas na exposição, mas nos exemplos internacionais muitos dos programas educativos integram estes recursos nas atividades, como é o caso da utilização de tablets no Museu Britânico e Museu da Acrópole.

Um outro fator essencial é a adaptação do programa aos diferentes visitantes. Esta adaptação passa, inicialmente, pela formação do serviço educativo do museu, uma vez que a formação dos monitores é essencial para uma comunicação eficaz. Para além da formação, é fundamental a disponibilidade da equipa para a conceção de um plano educativo que tenha em consideração os diferentes tipos de públicos, incluindo os adolescentes. Esta adaptação passa também pelo desenvolvimento de estratégias dinâ- 
micas e diversificadas, que conduzam a diferentes formas de criação de conhecimento e participação, e sejam adaptadas aos diferentes públicos.

Nos programas educativos dos museus selecionados, nacionais e internacionais, é clara a preocupação em adaptar o programa ao público escolar. Nos casos nacionais predominam as atividades ao ensino básico e em menor número ao ensino secundário. Isto deve-se, essencialmente, ao facto de ao longo do $1^{\circ}, 2^{\circ}$ e $3^{\circ}$ Ciclo do ensino básico ser lecionada a disciplina de História, sendo que a partir do Secundário apenas a área de Línguas e Humanidades tem esta disciplina, onde é lecionada, essencialmente, História Contemporânea. Nos casos internacionais, contudo, verifica-se não só um maior número de temáticas, mas também uma maior presença de atividades dedicadas ao ensino secundário.

O último fator essencial é a realização de atividades dinâmicas e diversificadas. Devem-se realizar num clima agradável, de acordo com os interesses do individuo, e com base num processo educativo que permite não só aprender, mas também partilhar. São ações que se baseiam no Modelo Educacional, que tem como objetivo promover a aprendizagem básica da arqueologia e os seus métodos, assim como a importância de proteger e conservar o património arqueológico, e Modelo de Relações Públicas, cujo objetivo é dar a conhecer a popularidade da arqueologia e a sua função na sociedade contemporânea, em que o público é visto como o objeto de intervenção, a quem é necessário comunicar e educar.

O museu PO.RO.S refere a existência de “(...) oficinas de arqueologia, oficinas de mosaicos, oficinas de vestuário romano e oficinas de escrita", o MAC também menciona que "no que respeita aos tipos de atividades podemos destacar(...)as visitas jogo, oficinas de férias, workshops e visitas orientadas" e o MNA "(...) oferece um vasto e diversificado conjunto de ações pedagógico-formativas (vistas orientadas, visitas orientadas com dramatização, ateliês, oficinas, entre outras)". Também no programa educativo do Museu D. Diogo de Sousa e Museu de Foz Côa o mesmo se verifica, diversas iniciativas à base de oficinas, ateliês, jogos, apresentações e visitas guiadas.

Nos programas educativos dos museus internacionais analisados destacam-se atividades similares dedicadas a diversos temas onde se procura explorar não só o acervo, mas também a característica multidisciplinar da arqueologia.

De forma geral, museu nacionais e internacionais se- guem uma estratégia educativa semelhante. A partir destas oficinas, ateliês, workshops e outras atividades procura-se interagir diretamente com o público de uma forma participativa e criativa que promove uma aprendizagem ativa.

Porém, serão estas linhas de acção suficientes para os museus de arqueologia nacionais conseguirem captar o público adolescente? A partir das entrevistas realizadas aos museus é possível verificar que, apesar do seu programa educativo exemplar, a sua captação continua um desafio (Gráfico 1).

O gráfico apresentado mostra que a maioria dos jovens se desloca ao museu no contexto de visitas escolares e em família, sendo que as visitas entre pares ou com amigos e as visitas individuais são pouco ou nada frequentes. O museu PO.RO.S e o MNA identificaram que as visitas em grupo escolar são "bastante frequentes", as visitas em família "frequentes", as visitas entre pares "pouco frequentes" e visitas individuais "nada frequentes". O MAC, por sua vez, identificou que as visitas em grupo, em família e entre pares são "pouco frequentes" e as visitas individuais "nada frequentes". Relativamente às visitas entre pares e as visitas individuais são pouco ou nada frequentes nos três museus, o que consideramos que vai de encontro às investigações de Kelly (2009) e de Cardoso (2013), os jovens não têm interesse em visitar museus fora do contexto escolar excetuando quando o fazem com familiares. Assim, consideramos que é essencial começar a cativar os jovens para a visita entre pares e individual. A segmentação deste público-alvo por "grupo escolar" é importante especialmente devido ao papel educativo, no entanto, observamos também que é necessário começar a encarar este público de uma forma mais específica, em que sejam considerados os seus interesses e necessidades pessoais.

Posteriormente foi colocada a questão de como é avaliada a capacidade do museu em captar o público jovem entre os 13 e os 17 anos (Gráfico 2).

O MAC e o MNA identificaram a capacidade do seu museu como "difícil”, o PO.RO.S foi o único a identificar a sua capacidade como "muito fácil”. Isto deve-se essencialmente ao facto de o museu ser um Centro Interpretativo profundamente interativo enquanto o MNA e o MAC têm um carácter mais tradicional. Consideramos, efetivamente, que a capacidade do museu PO.RO.S em atrair os jovens é superior quando comparada com os restantes museus analisados. 
Contudo, quando questionados pela capacidade da própria arqueologia em captar este público, as respostas foram semelhantes. Os museus acordam que é "difícil" no caso do MNA e MAC e "muito difícil" segundo o PO.RO.S (Gráfico 3).

Consideramos que isto se deve ao facto de os jovens não verem interesse na arqueologia que lhes é apresentada. O que eles veem, por outro lado, é um grande número de peças e objetos arqueológicos espalhados, uns mais interessantes que outros, mas sem contexto e sem uma história visível. Outro fator é que a arqueologia que lhes é apresentada é a real e não a versão fantasiosa. Por outro lado, acreditamos que a arqueologia tem fortes capacidades de cativar os jovens, simplesmente tem de ser apresentada tendo em conta os seus interesses. É importante estabelecer uma ponte entre a arqueologia real a aquela apresentada na cultura popular, mostrar que a arqueologia pode ser imersiva e cativante de uma forma autêntica e ética.

\section{PROPOSTAS PARA CAPTAÇÃO DO PÚBLICO ADOLESCENTE}

Os museus de arqueologia como instituições que visam a proteção, valorização e divulgação do património arqueológico, e os seus serviços educativos, que têm como principal objetivo uma comunicação educativa e o desenvolvimento de estratégias pedagógicas dedicadas a todos os públicos, são agentes imprescindíveis na educação patrimonial juntos dos jovens. No entanto, podemos concluir que os adolescentes são um público que os museus têm vindo a ter dificuldade em cativar. Ainda assim acreditamos que existem procedimentos que podem obter sucesso na sua captação.

Numa primeira fase, acreditamos que uma ação fundamental é começar a dissolver o conceito do museu como uma "instituição aborrecida", formal e pouco convidativa, e começar a divulgar uma imagem mais informal, social e passível de entretenimento. Apostar num museu participativo que passe não só pela conceção da própria exposição e atividades pedagógicas, como também se estenda a todos os funcionários do museu (SIMON 2010). Assim, propomos um contacto próximo entre funcionários, desde monitores a assistentes de sala, e jovens. Comunicar com o jovem não só através das repreensões, muitas vezes necessárias, mas também através da própria exposição ou atividades. Incentivar o jo- vem a dar a sua opinião, a discutir a exposição com os amigos e familiares.

Uma outra proposta é a divulgação mais extensiva do museu e das suas atividades, eventos e projetos. Esta deve ser realizada tanto a nível presencial como à distância, a partir de plataformas digitais. A Festa da Arqueologia realizada pelo Museu Arqueológico do Carmo, por exemplo, tem uma grande capacidade divulgativa junto do público, especialmente por ser gratuita e se realizar num ponto turístico da cidade. A organização de eventos à noite, como as "Noites no Museu" que se têm vindo a desenvolver e outros eventos temáticos, podem ter também uma forte componente divulgativa que fornece ao museu uma imagem mais informal e convidativa.

Propomos também uma abordagem mais direta e pessoal. É importante sair à rua e falar com os jovens sobre o que o museu tem para oferecer, questionálos sobre o que eles gostariam de ver num museu de arqueologia, conhecer os seus interesses e interagir pessoalmente.

Ainda no âmbito da divulgação acreditamos que é também importante inserir o museu no dia-a-dia do adolescente, isto é, introduzir o museu no mundo e realidade dos jovens. Aqui não propomos apenas a utilização das redes sociais como Facebook, Twitter e Instagram, que também podem ser eficazes, mas a utilização de outras plataformas de comunicação digital como o Youtube ou Twitch, que podem ser aplicadas em diversas funções, desde a partilha em direto de um determinado evento a ocorrer no museu, até à criação de pequenos episódios semanais ou mensais que abordam um determinado objeto, exposição ou temática específica relacionada com o museu.

Relativamente às estratégias de comunicação e mediação educativa, propomos a criação de atividades que sejam destinadas especificamente ao jovem, isto é, programas divididos em $1^{\circ}$ e $2^{\circ}$ Ciclo, $3^{\circ}$ Ciclo e Ensino Secundário, isto porque não consideramos viável a conceção de uma atividade que seja destinada a um público que vai desde os 6 aos 18 anos, mas sim atividades segmentadas, concebidas e dedicadas especificamente ao adolescente.

Um outro fator a ter em consideração, aquando do desenvolvimento de estratégias educativas, é o reconhecimento do jovem como um membro ativo da sociedade. Assim, propomos um incentivo ao desenvolvimento de projetos nos museus criados pelos próprios jovens, como se sucedeu com o pro- 
jeto Londinium $2012^{3}$ em que os jovens criaram e desenvolveram o seu próprio projeto com base na coleção Romana do Museu de Londres. Um projeto semelhante nos museus nacionais podia ser igualmente interessante e eficiente na captação deste público. Para a sua realização é, contudo, importante que haja algum tipo de compensação que motive os jovens. Como por exemplo a facultação de um passe combinado para transportes ou reembolso dos custos de deslocação, um certificado do próprio museu e, essencialmente, a oportunidade de partilharem os seus projetos com a comunidade através de uma exposição temporária ou um evento social.

Dentro deste âmbito também sugerimos a integração dos adolescentes na própria orgânica do museu, à semelhança da Junction Youth Panel ${ }^{4}$ do Museu de Londres, permitindo que um grupo de jovens não só desenvolva projetos, em cooperação com o museu e serviços educativos, como também partilhe as suas ideias, perspetivas e estratégias.

Relativamente aos programas educativos propomos a realização de atividades mais diversificadas, interativas e desafiantes. É importante conceber projetos em que os jovens possam manipular a sua própria experiência museal, com base nos seus interesses e temáticas. Os ateliês, oficinas e jogos são boas estratégias, porém é necessário diversificar a oferta educativa. Para além destas atividades, seria interessante incorporar debates temáticos em torno de questões recentes, mas com ligação ao passado, e que incentivem a participação do jovem, como concursos de arte, fotografia ou até de curta-metragem relacionados com a exposição do museu, dando posteriormente oportunidade de partilhar os resultados com a comunidade. Dentro dos programas propomos também abordagens ligadas à cultura popular da arqueologia, isto é, atividades que permitam criar paralelos entre os filmes, séries televisivas ou videojogos e, simultaneamente, desmistificar a imagem que os jovens têm da arqueologia.

Quanto aos recursos didáticos sugerimos também

3. Projeto criado e desenvolvido por cerca de 100 jovens londrinos, com o objetivo de dar a conhecer uma nova perspetiva da coleção Romana do Museu de Londres (GUARDIAN, 2012).

4. Um grupo de jovens consultantes que trabalha em conjunto com o Museu de Londres para assegurar que os diferentes projetos, eventos e exposições atarem os jovens (SHRAPNEL, 2012). uma diversificação, não só a nível expositivo, mas também relativamente aos recursos utilizados nas atividades dirigidas a públicos específicos. A integração de réplicas manuseáveis na exposição, a utilização de tablets, máquinas fotográficas ou telemóveis como parte da atividade pedagógica, ou a criação de uma plataforma online, seja um blog ou website, são recursos que captam a atenção do adolescente, especialmente se forem utilizados em contexto de exposição ou atividade. Os recursos de caráter tecnológico e inovador têm especial impacto na captação deste público, não só porque se trata de uma geração que tem crescido num ambiente rodeado de tecnologia, mas também porque os próprios recursos são interativos e imersivos. Nos museus que tenham a oportunidade, consideramos viável a integração destes tipos de recursos, que podem ir de simples maquetes e quadros interativos a salas imersivas de realidade aumentada.

A terminar, propomos uma exploração mais intensiva da característica multidisciplinar da arqueologia, assim como a sua importância para a sociedade de hoje. É essencial apresentar a arqueologia e a visita ao museu arqueológico não só como um complemento escolar, mas também como um local passível de adquirir novos conhecimentos, de modo a que o jovem crie uma ligação e, sucessivamente, sinta a necessidade de proteger e valorizar esse mesmo património. No desenvolvimento destas propostas não foram negligenciados os aspectos burocráticos, como a carência de funcionários dos serviços educativos de alguns museus, ou o baixo financiamento da maioria dos museus públicos. Contudo, muitas das sugestões podem ser postas em prática, essencialmente aquelas dirigidas à adaptação e realização de estratégias educativas dedicadas especificamente ao público adolescente.

\section{CONSIDERAÇÕES FINAIS}

Ao longo das últimas décadas os museus de arqueologia têm demonstrado uma forte evolução não só a nível educativo e comunicativo, mas também como espaços de entretenimento cada vez mais diversificados e inclusivos. Ainda assim, são poucos os adolescentes que visitam estes museus por iniciativa própria e como forma de entretenimento pessoal, não apenas devido á existência de uma grande panóplia de locais que vão mais de acordo com os seus interesses, mas também porque não encaram o museu 
e as suas exposições como um local de socialização. Por outro lado, os próprios museus não consideram os adolescentes como um grupo de indivíduos com interesses e necessidades específicas, que não se enquadram no público infantil nem no público adulto. Apesar das dificuldades de captar este público, acreditamos que os museus de arqueologia detêm as ferramentas necessárias para criar ofertas atrativas e determinantes no aumento destes visitantes. São espaços preparados para receber o público, são versáteis do ponto de vista temático e formados por equipas de profissionais qualificados na adaptação da mensagem científica e na criação de projetos e atividades. As realizações destas atividades não só são fundamentais na aprendizagem não-formal, como têm forte influência na imagem do museu. Com efeito, as apostas em projetos inovadores têm impacto na imagem transmitida aos adolescentes, são ações que dão ao museu uma representação mais juvenil e menos formal que o afasta de uma imagem meramente educativa, tornando-o, aos olhos do jovem, num espaço menos aborrecido e mais interativo.

Assim, consideramos que existem três soluções fundamentais para a baixa procura por parte dos adolescentes. Variar nas formas de divulgação e difundir a imagem do museu como um local de entretenimento informal, reconhecer o público adolescente como um novo tipo de público e, fundamentalmente, diversificar a oferta educativa para os adolescentes entre os 13 e os 17 anos.

A concluir, é de grande importância que exista uma preocupação com a educação e captação do público jovem no contexto dos museus arqueológicos. A adolescência, por ser uma fase de transição, é um período fundamental na formação do adulto e, com efeito, a altura ideal para fomentar o conceito e importância da valorização e proteção do património arqueológico. A captação deste público é também um importante fator para o museu, uma vez que não só implica o aumento das visitas, mas também pode causar impactos positivos no ciclo da instituição.

\section{BIBLIOGRAFIA}

ALMANSA SÁNCHEZ, Jaime (2011) - Arqueologia para todos los publicos. Hacia de una definición de la arqueologia publica "a la española". In Arqueweb: Revista sobre arqueologia en Internet, Vol. 13, pp. 87-107.

ALMEIDA, A. (2005) - O contexto do visitante na experiência museal: semelhanças e diferenças entre museus de ciência e de arte. In História, Ciências, Saúde. Vol. 12, pp. 31-53.
ANDERSON, D.; HORLOCK, N.; JACKSON, T. (2000) - Testing the Water: Young people and galleries. Liverpool University Press: Liverpool.

ANTAS, Mário (2013) - A Comunicação Educativa como factor de (re)valorização do Património Arqueológico: Boas Práticas em Museus de Arqueologia Portugueses. Dissertação de doutoramento em Museologia apresentada à Universidade Lusófona de Humanidades e Tecnologias.

BAHN, Paul (1997) - Arqueologia. Uma breve introdução. Gradiva: Lisboa.

BIRKETT, Dea (2012) - Kids in Museums. In MENDES, Luis (org.) - Reprograme Comunicação, Branding e Cultura numa nova era de museus, Vol. 1, pp. 118-122.

CARDOSO, Cristina (2013) - Jovens, Museus e Redes Sociais: Intervir em prol da relação através de um serviço educativo. Dissertação de mestrado em Ciências da Educação apresentada à Faculdade de Psicologia e de Ciências da Educação da Universidade do Porto.

COLOMER, Laia (2002) - Educational facilities in archaeological reconstructions: Is a image worth more than a thousand words. In: Public Archaeology, Vol. 2, pp. 85-94.

CRACKNELL, Stephen, CORBISHLEY, Mike (1986) - Presenting archaeology to young people. Council for British Archaeology: Research Report $\mathrm{Nr}^{\circ} 64$.

FAUSTINI, Marcus (2012) - A relação entre museus e jovens. In MENDES, Luis (org.) - Reprograme Comunicação, Branding e Cultura numa nova era de museus, Vol. 1, pp. 123-129.

GUARDIAN (2012) - Museum of London - Junction - Introducing the Museum of London's youth panel. The Guardian: https://www.theguardian.com/culture-professionalsnetwork/culture-professionals-blog/2012/mar/13/museums-junction-engage-young-people. Acedido a o8, Julho, 2020.

HOLTORF, Cornelius (2004) - Doing Archaeology in popular culture. In The Interplay of the Past and Present, Lund University, pp. 41-49.

JAMESON JR, Jonh; BAUGHER, Sherene (2007) - Past Meets Present archaeologist partnering with Museum Curators, Teachers, and Community Groups. Springer: New York.

KELLY, Lynda; BARTLETT, Allison (20o9) - Young People and Museums. Acedido a 11, Junho, 2020 em: https://australianmuseum.net.au/young-people-and-museums

KORN, R. (2008) - Audience Research: Young Adult Study. Randi \& Korn Associates: Boston.

LOURENÇO, Andreia Vale (2014) - Reflexões sobre diversidade de representações de públicos e de estratégias interpretativas. In: MIDAS: Revista Online, Nroำ 4, pp. 213.

MATSUDA, AKIRA (2004) - The Concept of "the Public" and the Aims of Public Archaeology. In Papers from the Institute of Archaeology, Vol. 15, UCL: Institute of Archaeology, pp. 66-74. 
MATSUDA, Akira (2016) - A consideration of public archaeology theories. In: Public Archaeology, Vol. 15, pp. 15, pp. 40-49.

MCCARTHY, C., MANSON, D. (2006) - The feeling of exclusion: young people's perceptions of art galleries. In $\mathrm{Mu}$ seum Management and Curatorship, Vol. 21, Nrº. 1, pp. 20-31.

RAMALHO, Maria Magalhães (1993) - O arqueólogo, o público, o passado e os seus amantes. In: Almadan: IIo Série, $\mathrm{Nr}^{2}$ 2, pp. 5657 .
SANTOS, Joana Cristina (2014) - Públicos dos museus: um estudo qualitativo sobre as visitas em família: o caso do Museu da Eletricidade. Dissertação de mestrado em Gestão e Estudos da Cultura apresentada ao Instituto Universitário de Lisboa.

SHRAPNEL, Emma (2012) - Engaging Young adults in the museums An Audience Research Study. Acedido a 11, Junho, 2020 em: https://australianmuseum.net.au/document/ engaging-young-adults-in-museums

SIMON, Nina (2010) - The Participatory Museum. MUSEUM: California.

\begin{tabular}{|c|c|}
\hline Casos Internacionais & Resumo Programa de Atividades \\
\hline Museu Britânico & $\begin{array}{l}\text { - Atividades de contexto escolar ( } 3 \text { aos } 16 \text { anos } />16 / \text { necessidade especiais. } \\
\text { - Ateliê de Culturas e Contextos Históricos }(3 \text { aos }>16) \\
\text { - Ateliês de Tópicos específicos (arqueologia/arte/etc) }(3 \text { aos }>16) \\
\text { - Londinium } 2012 \\
\text { - Junction Youth Panel }\end{array}$ \\
\hline Museu da Acrópole de Atenas & $\begin{array}{l}\text { - Visitas temáticas e orientadas }(7 \text { aos }>16) \\
\text { - Ateliês, Workshops e Jogos Lúdicos }(7 \text { aos }>16)\end{array}$ \\
\hline $\begin{array}{l}\text { Jorvik - Centro Viking (Parque Arqueológico de York, Reino } \\
\text { Unido) }\end{array}$ & $\begin{array}{l}\text {-Workshop Periodo Viking/Anglo-saxónico (Público em geral) } \\
\text { - Escavações / Manuseamento de Material (Público em geral) }\end{array}$ \\
\hline $\begin{array}{l}\text { Parque Nacional do Património Irlandês (Parque } \\
\text { Arqueológico) }\end{array}$ & $\begin{array}{l}\text { - Workshops educacionais (Público escolar) } \\
\text { - Visitas Guiadas (Público em geral) } \\
\text { - Atividades temáticas (Público em geral) } \\
\text { - "The Big Dig" (+ } 10 \text { anos) }\end{array}$ \\
\hline
\end{tabular}

Tabela 1 - Resumo do Programa de atividades dos Casos de Estudo Internacionais Selecionados.

\begin{tabular}{|c|c|}
\hline Casos Nacionais & Resumo Programa de Atividades \\
\hline Museu Arqueológico do Carmo (MAC) & $\begin{array}{l}\text { - Atividades temáticas ( } 6 \text { aos } 18 \text { anos) } \\
\text { - Visitas Jogo (6 aos } 18 \text { anos) } \\
\text { - Atividades de Arqueologia (6 aos } 15 \text { anos) } \\
\text { - Festa da Arqueologia }\end{array}$ \\
\hline Museu Regional de Arqueologia D. Diogo de Sousa & $\begin{array}{l}\text { - Visitas temáticas à exposição permanente ( } 3 \text { aos } 14 \text { anos) } \\
\text { - Oficinas lúdico-pedagógicas ( } 3 \text { aos } 14 \text { anos) } \\
\text { - Histórias e Contos ( } 3 \text { aos } 7 \text { anos) } \\
\text { - Jogos lúdico-pedagógicos ( } 8 \text { aos } 18 \text { anos; Ensino Profissional) } \\
\text { - Ludi-Saeculares. }\end{array}$ \\
\hline Museu Portugal Romano em Sicó (PO.RO.S) & $\begin{array}{l}\text { - Visitas Orientadas (6 aos } 18 \text { anos) } \\
\text { - Visitas Temáticas (6 aos } 18 \text { anos) } \\
\text { - Exposição tecnológica e interactiva. }\end{array}$ \\
\hline
\end{tabular}

Tabela 2 - Resumo do Programa de atividades dos Casos de Estudo Nacionais Selecionados. 
Frequência e Contexto da Visita

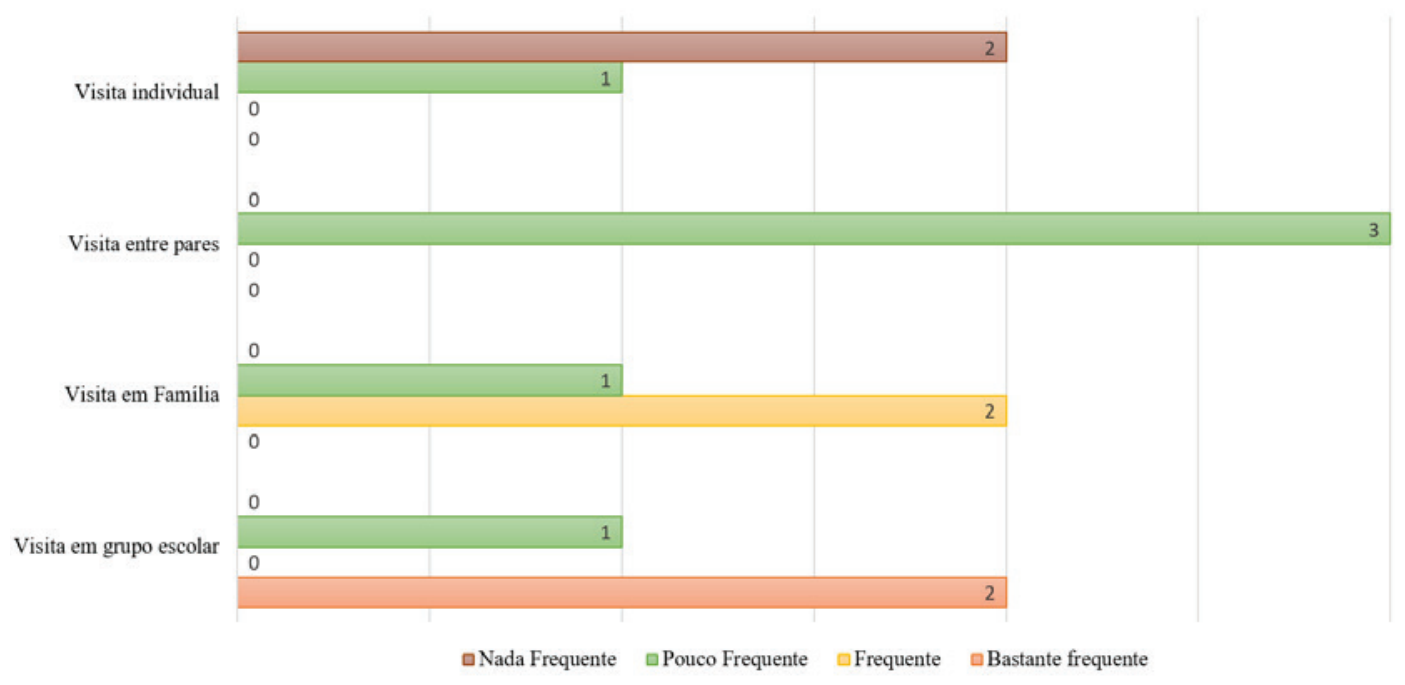

Gráfico 1 - Frequência e contexto em que os jovens entre os 13 e os 17 visitam os museus em estudo.

\section{Capacidade do Museu}

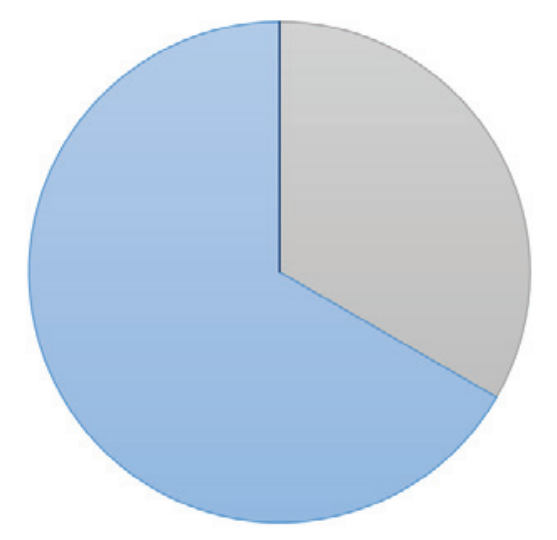

$\square$ Fácil $\square$ Muito Fácil $\square$ Dificil $\square$ Muito Dificil

Gráfico 2 - Capacidade dos museus em estudo em captar o público entre os 13 e os 17 anos.

\section{Capacidade da Arqueologia}

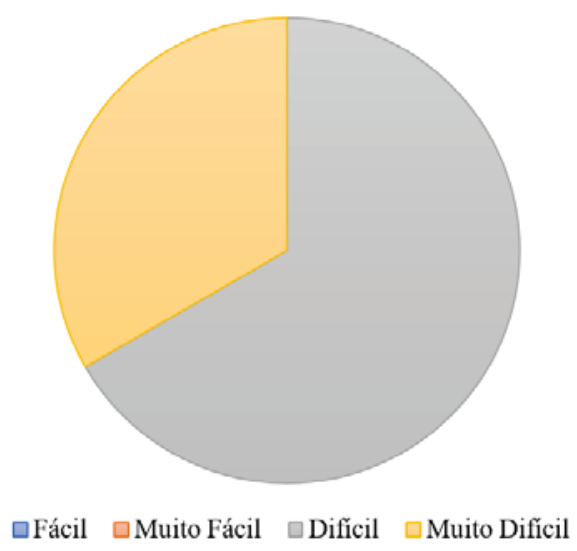

Gráfico 3 - Capacidade da arqueologia na captação do público jovem entre os 13 e os 17 anos. 


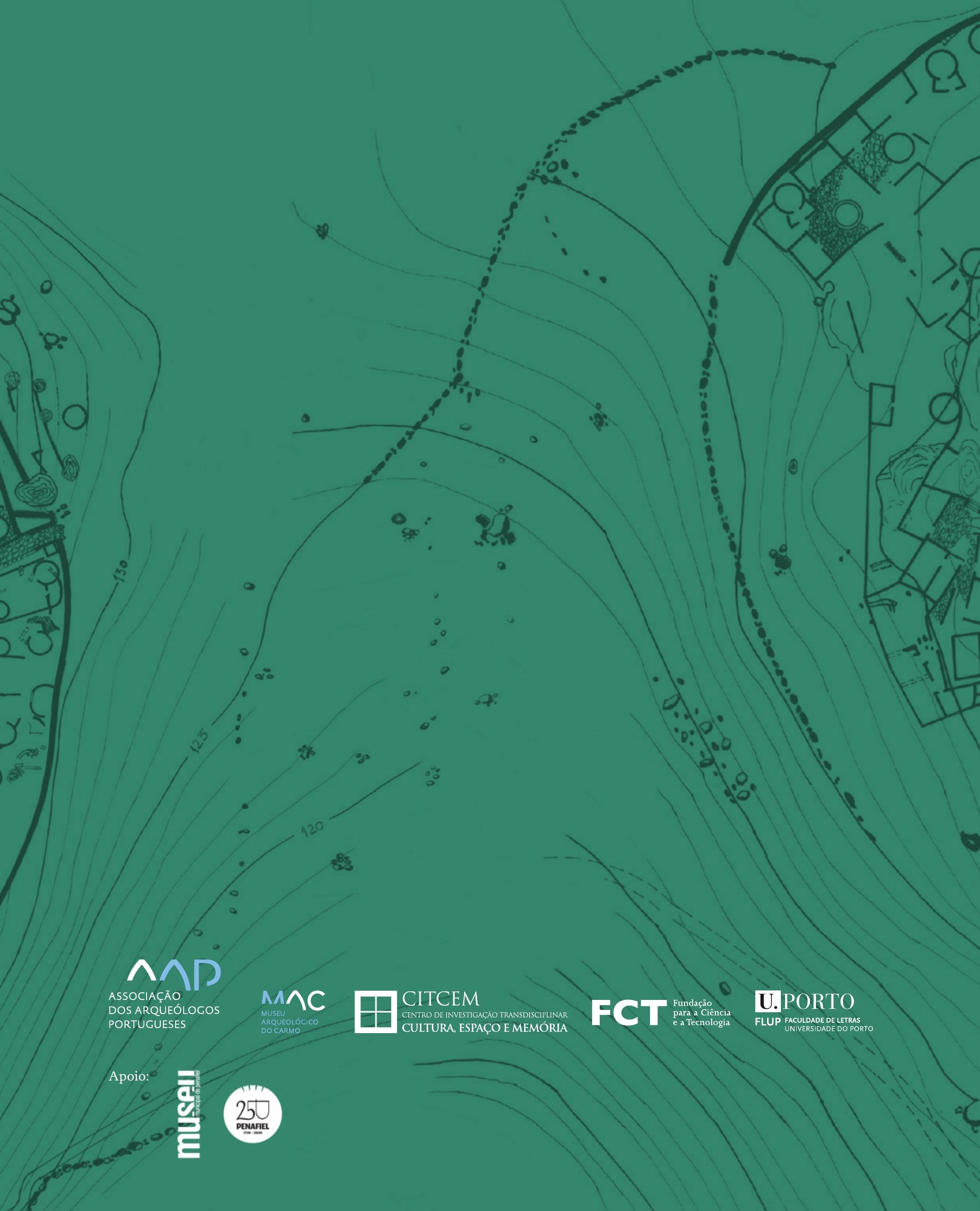

